\title{
Total Diet Approach to Cancer Prevention: A Narrative Review of the Literature Since 2011 Concerning the Association of Colorectal Cancer and Meat Consumption
}

\author{
Krista E. King \\ Patricia M. Sheean \\ Loyola University Chicago
}

Follow this and additional works at: https://ecommons.luc.edu/nursing_facpubs

Part of the Nursing Commons

\section{Recommended Citation}

King, Krista E. and Sheean, Patricia M.. Total Diet Approach to Cancer Prevention: A Narrative Review of the Literature Since 2011 Concerning the Association of Colorectal Cancer and Meat Consumption. Journal of Clinical Nutrition \& Dietetics, 2, 3: 1-11, 2016. Retrieved from Loyola eCommons, Nursing: School of Nursing Faculty Publications and Other Works, http://dx.doi.org/10.4172/2472-1921.100025

This Article is brought to you for free and open access by the Faculty Publications and Other Works by Department at Loyola eCommons. It has been accepted for inclusion in Nursing: School of Nursing Faculty Publications and Other Works by an authorized administrator of Loyola eCommons. For more information, please contact ecommons@luc.edu.

\section{(c) (i)}

This work is licensed under a Creative Commons Attribution 3.0 License.

(c) King KE, Sheean PM, 2016. 


\section{Total Diet Approach to Cancer Prevention: A Narrative Review of the Literature Since 2011 Concerning the Association of Colorectal Cancer and Meat Consumption}

\section{Abstract}

Diet serves as a primary prevention approach to reduce the global burden of cancer. In 2007, the World Cancer Research Fund and the American Institute for Cancer Research published the Second Expert Report (SER) Food, Nutrition, Physical Activity, and the Prevention of Cancer: A Global Perspective outlining lifestyle recommendations for primary cancer prevention. Results support a strong link between red and processed meat and colorectal carcinogenesis. Findings from the Colorectal Cancer 2011 Report: Food, Nutrition, Physical Activity, and the Prevention of Colorectal Cancer, a review conducted through the WCRF Continuous Update Project (CUP), strengthened the evidence and supported the conclusions found in the SER. This review explored the available evidence since the publication of the 2011 CUP report and provides an update of the literature, specific to colorectal cancer (CRC) and diet. Furthermore, several proposed mechanisms, including heterocyclic amines (HCAs), polyaromatic hydrocarbons (PAHs), N-nitroso compounds (NOCs), and heme iron, may explain the effects of meat on the cancer process. The studies reviewed continue to support the causal link between red and processed meat consumption and CRC. The most recent literature supports the preventative role of consuming a plant-based diet low in red and processed meat for overall cancer prevention.

Keywords: Colorectal cancer; Cancer prevention; Diet; Iron; Cancer risk

Abbreviations: ACS: American Cancer Society; AICR: American Institute for Cancer Research; AND: Academy of Nutrition and Dietetics; CRC: Colorectal Cancer; DiMelQx: 2-amino-3,4,8-dimethylimidazo[4,5-f]quinoxaline; FFQ: Food Frequency Questionnaire; HCA: Heterocylic Amines; MelQx: 2-amino-3,8dimethylimidazo[4,5-f]quinoxaline; $\mathrm{NCl}$ : National Cancer Institute; NOCs: N-Nitroso Compounds; PAH: Polycyclic Aromatic Hydrocarbons; PhIP: 2-amino-1methyl-6-phenylimidazo(4,5,b)pyridine; SER: Second Expert Report; WCRF: World Cancer Research Fund; WHO: World Health Organization

Received: July 04, 2016; Accepted: September 12, 2016; Published: September 19, 2016

\section{Introduction}

Although the exact causes of cancer are unknown and genetic predisposition may afford an elevated risk, approximately 30-40 percent of cancers are preventable over time through lifestyle behaviors, such as smoking, diet, and physical activity [1]. Specifically, energy dense dietary consumption and
Krista E King ${ }^{1}$ and Patricia M Sheean ${ }^{2}$

1 Momentum Health - Employee Engagement Solutions, Illinois, USA

2 Loyola University Chicago, Illinois, USA
Đ keking@gmail.com

Director of Clinical Services, Momentum Health - Employee Engagement Solutions, LLC, 125 South Wacker Drive, Suite 2155, Chicago, Illinois 60606, USA.

Tel: 248-931-0674

Citation: King KE, Sheean PM. Total Diet Approach to Cancer Prevention: A Narrative Review of the Literature Since 2011 Concerning the Association of Colorectal Cancer and Meat Consumption. J Clin Nutr Diet. 2016, 2:3. 
projection of obesity leading to about 500,000 additional cancer cases by 2030 [2]. Therefore, maintaining a normal weight and preventing weight gain over the lifespan through healthy eating and daily physical activity reflect foundational evidence-based strategies for cancer prevention.

In 2007, the World Cancer Research Fund (WCRF) and the American Institute for Cancer Research (AICR) published the Second Expert Report (SER) Food, Nutrition, Physical Activity, and the Prevention of Cancer: A Global Perspective, which reflects a synthesis of the current literature and outlines the top recommendations for cancer prevention. In general, the SER committee recommended following a plant-based diet by eating a variety of vegetables, fruits, whole grains, and legumes, while limiting the consumption of red meat ${ }^{1}$ and avoiding processed meat $^{2}$. Some of the strongest evidence from this report reveals a significant 'cause and effect' relationship between the consumption of red and/or processed meat consumption and the development of colorectal cancer (CRC) [1]. The American Cancer Society (ACS) projected that in 2015, 69,090 men and 63,610 women will receive a CRC diagnosis and ultimately close to 50,000 combined deaths from CRC will occur [3]. As such, it is imperative to identify prevention strategies to decrease the overall burden of CRC over time. Through the Continuous Update Project (CUP), the WCRF went on to publish the 2011 Food, Nutrition, Physical Activity, and the Prevention of Colorectal Cancer, which includes new scientific findings since the publication of the original report. Consistent with findings from the SER, the CUP panel also concluded that both red and processed meat continue to be convincing causes of CRC [4]. New research has emerged since the publication of this report regarding the associations between diet and CRC. Therefore, the objective of this narrative review is to provide a review of the literature since the 2011 CUP report, including the proposed mechanisms and biological plausibility of meat consumption and cancer development.

\section{Methodology}

A comprehensive literature search was conducted using the PubMed (NIH) database (2009-2015). The search was limited to human studies published in English. Keyword combinations of the medical subject headings (MeSH) included: "processed meat", "red meat", "red meat intake", "processed meat intake", "frequency of meat consumption", "cancer", "colorectal cancer", "colorectal cancer risk", "heterocylic amines", "HCA", "welldone meat", "cooked meat", "cooking methods" "cooking practices", "iron", "heme iron", "nitrate", "nitrite", or "N-nitroso compounds". A secondary search was conducted by reviewing the references of articles to identify further manuscripts for inclusion and critical review.

${ }^{1}$ According to the SER 'red meat' refers to "beef, pork, lamb, and goat from domesticated animals including that contained in processed foods" [1].

${ }^{2}$ According to the SER 'processed meat' refers to "meat preserved by smoking, curing or salting, or addition of chemical preservatives, including that contained in processed foods" [1].

\section{Results}

Figure 1 depicts the search strategy and paper selection process. Initially, 858 papers were reviewed; however, 20 papers were deemed evaluable, after duplicative papers and further search restrictions were applied. The following sections summarize the results of the literature review including compounds formed from high-heat cooking methods, nitrates/nitrites in processed meat, and heme iron. Tables 1-4 provide a summary of the studies, describing the study design, key characteristics of the population, dietary assessment methodologies, results and significant findings.

\section{Meat consumption and colorectal cancer}

The negative effects of animal-based protein are most pronounced in CRC [1]. The SER states that there is convincing evidence to support red meat as a cause of CRC, with cohort data demonstrating a dose-response relationship. The WCRF/AICR guideline recommends limiting consumption of red meat, such as beef, pork, and lamb, to no more than 18 ounces per week and avoiding processed meats, such as ham, bacon, salami, hot dogs, and sausages [1]. Since the publication of the SER, six studies have been published, four cohort studies and two case-control studies on the link between CRC and red meat consumption. Of these studies, five supported that consuming red or processed meat was associated with development of CRC, while one case control investigation concluded that there was insufficient evidence to support this relationship. These studies are summarized in Table 1.

The five studies in support of the relationship between meat and elevated CRC risk included three cohort and two case-control studies. In a prospective cohort investigation, the role of meat

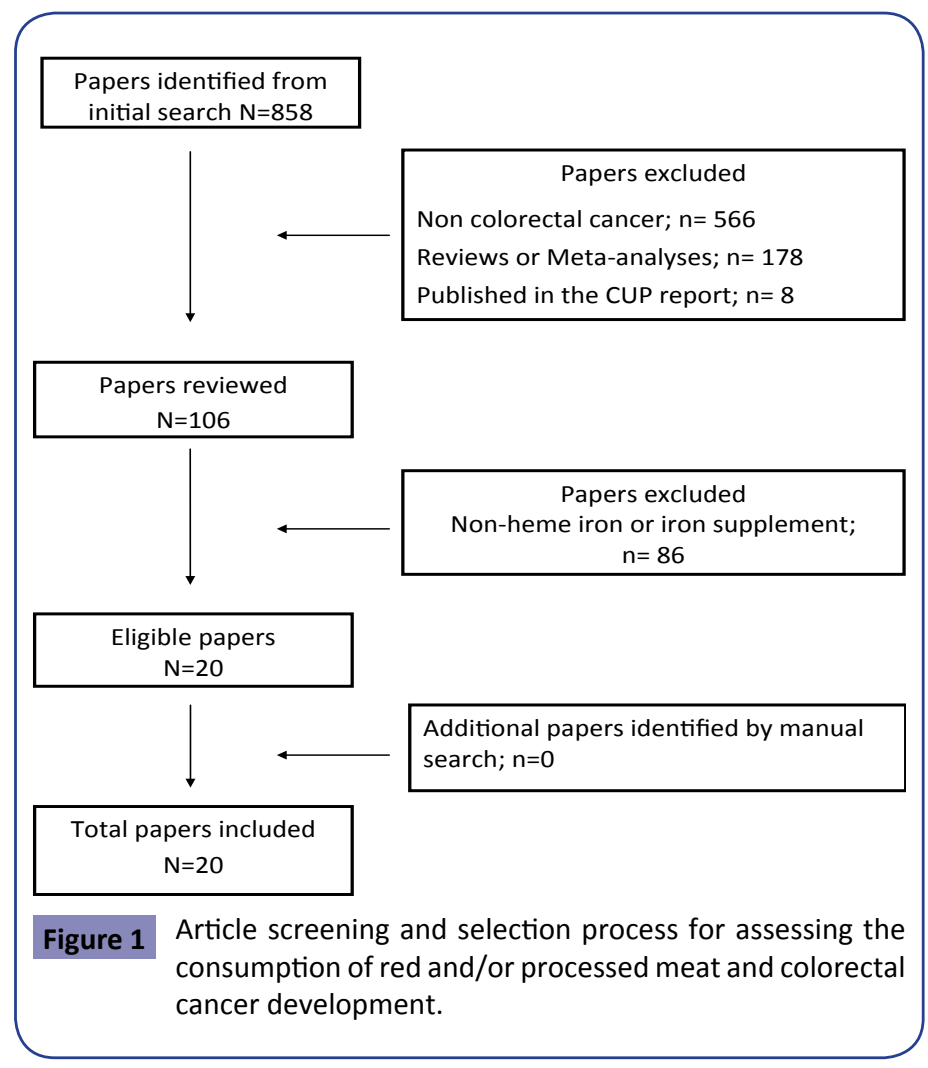


Table 1 Association between red, processed meat consumption and CRC.

\begin{tabular}{|c|c|c|c|c|}
\hline Citation/Topic & Study Design/Population & $\begin{array}{c}\text { Dietary Assessment } \\
\text { Method }\end{array}$ & Results & Major Findings/Conclusions \\
\hline $\begin{array}{l}\text { Ferrucci et al. [5] } \\
\text { Meat and distal colon } \\
\text { and rectal adenoma }\end{array}$ & $\begin{array}{l}\text { Prospective cohort study of } \\
\text { participants in the screening arm of } \\
\text { the Prostate, Lung, Colorectal, and } \\
\text { Ovarian Cancer Screening Trial who } \\
\text { underwent baseline and follow-up } \\
\text { sigmoidoscopy } \\
1008 \text { w/ incident distal CR adenoma }\end{array}$ & $\begin{array}{l}\text { 137-item FFQ on } \\
\text { usual intake of foods } \\
\text { and beverages during } \\
\text { the past year }\end{array}$ & $\begin{array}{c}\text { Positive associations found for } \\
\text { red (OR } 1.22,95 \% \mathrm{Cl} 0.98-1.52 \text { ) } \\
\text { and processed meat (OR 1.23, } \\
95 \% \mathrm{Cl} 0.99-1.54 \text { ), as well as } \\
\text { heme iron (OR } 1.23,95 \% \mathrm{Cl} \\
0.99-1.52 \text { ) and nitrate/nitrite } \\
\text { (OR } 1.22,95 \% \mathrm{Cl} 0.94-1.53 \text { ) }\end{array}$ & $\begin{array}{l}\text { Findings indicate that several } \\
\text { meat-related components } \\
\text { may be most relevant to early } \\
\text { neoplasia in the rectum }\end{array}$ \\
\hline $\begin{array}{l}\text { Takachi et al. [6] } \\
\text { Red meat and colon } \\
\text { cancer }\end{array}$ & $\begin{array}{l}\text { Prospective cohort study; Japanese } \\
\text { cohort of } 80,658 \text { men and women } \\
\text { age } 45-74\end{array}$ & $\begin{array}{c}\text { 138-item FFQ, } \\
\text { including } 16 \text { meat } \\
\text { items }\end{array}$ & $\begin{array}{c}\text { Significant association found } \\
\text { between higher red meat } \\
\text { consumption among women } \\
\text { (HR 1.48, } 95 \% \mathrm{Cl} 1.01-2.17 \text { ) and } \\
\text { higher total meat consumption } \\
\text { among men (HR 1.44, 95\% Cl } \\
1.06-1.98)\end{array}$ & $\begin{array}{l}\text { Red meat may increase } \\
\text { the risk of colon cancer } \\
\text { in middle-aged Japanese. } \\
\text { The highest quintile of red } \\
\text { meat consumption may be } \\
\text { considered moderate by } \\
\text { Western standards }\end{array}$ \\
\hline
\end{tabular}

Prospective cohort study of participants in the Nurses' Health

Bernstein et al. [7]

Processed and unprocessed meat and $\mathrm{CRC}$ risk Study (NHS) $(n=87,108$ women 1980-2010) and the Health

Professionals Follow Up Study (HPFS) ( $n=47,389$ men 1986-2010)

Combined cohorts $-2,731$ CRC cases
NHS: validated 61-

item FFQ in 1980,

expanded FFQ every

4 years from 1984 2010 to update dietary intake

HPFS: validated

131-tiem FFQ, administered every 4 years from 1990-2010
Multivariable analysis showed modest significant association found between processed red meat and CRC (HR 1.15, 95\% Cl 1.01-1.32)
A significant and positive association between processed red meat and CRC, particularly distal colon cancer, was observed
Aune et al. [8]

Meat and multiple cancer sites
Multisite case-control study of 11 cancer sites in Uruguay (19962004); 3539 cancer cases and 2032 hospital controls 64-item FFQ covering dietary intake one year before diagnosis
The highest risk was positively associated with meat-based pattern (OR 1.63, 95\% Cl 1.22

De Stefani et al. [9]

Dietary patterns and Case-control study in Uruguay; 611 CRC cases and 1,362 controls 64-item FFQ

4-7 day food diariesdisaggregated weights of meat,

Spencer et al. [10]

Meat, poultry, and fish and CRC
Case-control study with 579 cases of CRC matched with 1996 controls
2.18), where the plant-based pattern (OR $0.60,95 \% \mathrm{Cl} 0.45$ 0.81 ) was strongly protective with CRC risk

\section{Disaggregated intakes were} moderately low (e.g. mean day among male and $28.7 \mathrm{~g} /$ day among female controls) little evidence of association between red (OR $0.88,95 \% \mathrm{Cl}$ poultry, and fish from composite

foods to investigate dose-response relationships
High intake of red and processed meat was significantly associated (OR 3.83, $95 \% \mathrm{Cl}$ 2.37-6.20; OR 2.15, $95 \% \mathrm{Cl} 1.49-3.11$ respectively) with an increase in CRC
Results confirm the association between red and processed meat consumption and CRC risk, as well as several other cancer sites - oral cavity and pharynx, esophagus, larynx, stomach, lung, breast, prostate, bladder, and kidney

Meat-based pattern suggestive of highest CRC risk; since HCAs are formed in well-done meat, it is suggestive that meatbased pattern could be an important etiologic agent for CRC red meat intakes were $38.2 \mathrm{~g} /$ $0.68-1.15)$ and processed meat (OR 0.97, 95\% Cl 0.84-1.12) and risk of CRC consumption and risk of adenoma in the distal colon and rectum was investigated using 1008 individuals from the Prostate, Lung, Colorectal, and Ovarian Cancer Screening Trial with incident distal colorectal adenoma [5]. Positive associations were observed for red (odds ratio (OR) $1.22,95 \% \mathrm{Cl} 0.98-1.52$ ) and processed meat
(OR 1.23, 95\% Cl 0.99-1.54), as well as heme iron (OR 1.23, 95\% $\mathrm{Cl} 0.99-1.52$ ) and nitrate/nitrite (OR 1.22, 95\% Cl 0.94-1.53). The findings indicate early neoplasia in the rectum may be attributed to several meat-related components. In a cohort of middle-aged Japanese men and women, 1,145 cases of CRC were identified 
and the findings supported a significant association between higher red meat consumption among women ( $\mathrm{HR} 1.48,95 \% \mathrm{Cl}$ 1.01-2.17) and higher total meat consumption among men (HR $1.44,95 \% \mathrm{Cl} 1.06-1.98$ ) [6]. The increased risk of colon cancer with meat consumption was found in this population who have relatively low intakes of red meat compared to Western standards. Additionally, in a study of participants from the Nurses' Health Study and the Health Professionals Follow Up Study, multivariable analysis of a combined cohort of 2,731 CRC cases found a modest significant association between processed red meat and CRC (HR 1.15, 1.01-1.32) [7].

Two case-control studies were conducted in Uruguay. Aune et al. [8] assessed the associations between cancer risk and meat intake including 11 cancer sites and comprising 3,539 cancer cases and 2,032 hospital controls in Uruguay between 1996 and 2004. High intake of red and processed meat was significantly associated (OR 3.83, 95\% Cl 2.37-6.20; OR 2.15, 95\% Cl 1.49-3.11 respectively) with an increase in CRC. The case-control study by De Stafani et al. [9] explored the association between CRC risk and nutrient-derived dietary patterns. The study analyzed 611 cases of CRC and 1,362 controls and retained three factors: Meat-based, plant-based, and carbohydrate dietary patterns. The highest risk of CRC was positively associated with the meatbased pattern (OR 1.63, 95\% $\mathrm{Cl} 1.22-2.18$ ), whereas a strong protective effect was found with the plant-based pattern (OR $0.60,95 \% \mathrm{Cl} 0.45-0.81$ ) [9]. The findings of this study suggested that a meat-based dietary pattern was an etiologic agent for CRC.

Spencer et al. [10] matched 579 cases of CRC with 1,996 controls and used food diaries to examine dietary intake over 4-7 days. The results showed limited evidence to support the association between consumption of red (OR $0.88,95 \% \mathrm{Cl} 0.68-1.15)$ and processed meat (OR $0.97,95 \% \mathrm{Cl} 0.84-1.12$ ) and risk of CRC [10]. The authors noted that disaggregated intakes of red meat, or estimated amounts separated from mixed dishes (which tend to lead to overestimation of amounts consumed), were moderately low with mean red meat intakes of $38.2 \mathrm{~g} /$ day for male and 28.7 $\mathrm{g} /$ day for female controls [10].

Collectively, the majority of the studies included in this update since the CUP Report continue to support the cause and effect relationship between CRC risk and meat intake and the recommendation to limit red and processed meat for the prevention of CRC.

\section{Three Underlying Mechanisms and Biological Plausibility}

\section{Heterocyclic amines/polycyclic aromatic hydrocarbons and cooking methods}

Heterocylic amines (HCAs) and polycyclic aromatic hydrocarbons (PAHs) are chemicals formed from the reaction of creatine or creatinine, amino acids, and sugar in muscle meat using hightemperature cooking methods, such as pan frying or grilling directly over an open flame. The most important factor in the formation of HCAs and PAHs is temperature [11]. These mutagenic chemicals may cause DNA damage after specific enzymes in the body metabolize them through a process called "bioactivation." Evidence shows that HCA and PAH exposure can cause cancer in animal models [12]. While a definitive link between exposure to HCAs and PAHs has not been established in human studies, as it is difficult to determine the exact level of exposure to these chemicals, population based epidemiologic studies estimate exposure using detailed questionnaires. Table $\mathbf{2}$ summarizes the literature on six studies on the association between HCAs and CRC since the publication of the CUP Report. Of the studies assessed, three supported the association between HCAs and CRC and three indicated the evidence insufficient to support the association.

One cohort study and two case-control studies supported the association between HCAs and risk of CRC. A prospective cohort study analyzed data collected from the European Prospective Investigation into Cancer and Nutrition (EPIC) - Heidelburg Study [11]. HCA intake was estimated in 21,452 participants aged 35-65 who completed a follow-up food frequency questionnaire (FFQ) that included detailed questions on meat preparation methods and preferred degree of browning. Analysis showed that 2-amino-1-methyl-6-phenylimidazo(4,5,b)pyridine (PhIP), a HCA, was the most abundant dietary HCA associated with increased colorectal adenoma risk ( $R R$ 1.47, 95\% Cl 1.13-1.93), but 2-amino3,8-dimethylimidazo[4,5-f]quinoxaline (MeIQx) (RR 1.27, 95\% Cl 0.97-1.68) and 2-amino-3,4,8-dimethylimidazo[4,5-f]quinoxaline (DiMelQx) (RR 1.18, 95\% Cl 0.92-1.53), other HCAs, did not show statistically significant observations [11]. The results of this study support a positive association between intake of specific HCAs and risk of CRC. A case-control study assessed the associations between meat-related compounds as underlying mechanisms for CRC risk [12]. Participants included 989 cases and 1,033 healthy controls that completed a FFQ with a meat-specific module. Positive associations were observed for DiMelQx and colorectal (OR 1.36, 95\% Cl 1.02-1.82), distal colon (OR 1.66, 95\% Cl 1.062.59), and rectal (OR 1.54, 95\% $\mathrm{Cl} 1.02-2.33$ ) tumors [12]. In the case-control study by Helmus et al. [13], 1,062 incident colon cancer cases and 1,645 population controls completed a meat preparation questionnaire and reported statistically significant associations between dietary intake of MelQx (adjusted odds ratio (aOR) $1.88 \mathrm{Cl}$ 1.45-2.43), DiMelQx (aOR $1.73 \mathrm{Cl} 1.34-2.23$ ), meat-derived mutagenic activity (aOR $1.84 \mathrm{Cl} 1.42-2.39)$ and colon cancer carcinogenesis [13].

Two cohort studies and one case-control study concluded that there was insufficient evidence to support the association between HCAs and risk of CRC. A prospective cohort study conducted within the Multiethnic Cohort Study examined the association between CRC risk and consumption of total, red, or processed meat in 165,717 participants who completed a detailed FFQ [14]. This study assessed whether a greater estimated intake of HCAs had an association with risk of CRC among 131,763 participants who completed a follow up questionnaire with an added meatcooking module. While the relationship between meat or HCAs was not statistically significant (RR $0.90,95 \% \mathrm{Cl} 0.76-1.05$ ), the authors noted that they could not rule out the possibility that 
Table 2 Association between heterocyclic amines / polycyclic aromatic hydrocarbons, cooking methods, and CRC.

\begin{tabular}{|c|c|c|c|c|}
\hline Author/Topic & Study Design/Population & $\begin{array}{c}\text { Dietary Assessment } \\
\text { Method }\end{array}$ & Results & Major Findings/Conclusions \\
\hline $\begin{array}{l}\text { Rohrmann et al. } \\
\qquad[11] \\
\text { HCAs and CRC }\end{array}$ & $\begin{array}{l}\text { Prospective cohort study; } 25,540 \\
\text { participants of the European } \\
\text { Prospective Investigation into } \\
\text { Cancer and Nutrition-Heidelberg } \\
\text { cohort study, } 21,452 \text { completed } \\
\text { follow-up FFQ }\end{array}$ & $\begin{array}{l}\text { FFQ on meat } \\
\text { consumption, applied } \\
\text { cooking methods, and } \\
\text { preferred degree of } \\
\text { browning }\end{array}$ & $\begin{array}{c}\text { Intake of PhIP associated with } \\
\text { increased risk of CR adenoma (RR } \\
1.47,95 \% \mathrm{Cl} 1.13-1.93 \text { ) but no } \\
\text { statistically significant associations } \\
\text { observed for MelQx (RR } 1.27,95 \% \\
\mathrm{Cl} 0.97-1.68 \text { ) and DiMelQx (RR } \\
1.18,95 \% \mathrm{Cl} 0.92-1.53 \text { ) }\end{array}$ & $\begin{array}{l}\text { Support data from case-control } \\
\text { studies of a positive association } \\
\text { between HCA intake and CR } \\
\text { adenoma risk }\end{array}$ \\
\hline $\begin{array}{l}\text { Miller et al. [12] } \\
\text { Meat-related } \\
\text { compounds and } \\
\text { CRC }\end{array}$ & $\begin{array}{l}\text { Case-control; } 989 \text { cases/1,033 } \\
\text { healthy controls }\end{array}$ & $\begin{array}{l}\text { FFQ w/a meat-specific } \\
\text { module }\end{array}$ & $\begin{array}{c}\text { Significant positive association was } \\
\text { observed for HCA DiMelQx and } \\
\text { colorectal (OR 1.36, } 95 \% \mathrm{Cl} 1.02- \\
\text { 1.82), distal colon (OR } 1.66,95 \% \\
\mathrm{Cl} 1.06-2.59 \text { ), and rectal (OR } 1.54 \\
95 \% \mathrm{Cl} 1.02-2.33 \text { ) tumors }\end{array}$ & $\begin{array}{l}\text { HCAs, PAHs, nitrites, and } \\
\text { nitrates may be involved in CRC } \\
\text { etiology }\end{array}$ \\
\hline $\begin{array}{l}\text { Helmus et al. [13] } \\
\text { HCAs and CRC risk }\end{array}$ & $\begin{array}{l}\text { Case-control study of } 1,062 \\
\text { incident colon cancer cases and } \\
1,645 \text { population controls }\end{array}$ & $\begin{array}{l}\text { 175-item FFQ } \\
\text { and validated } \\
\text { meat preparation } \\
\text { questionnaire } \\
\text { adapted from a } \\
\text { National Cancer } \\
\text { Institute HCA } \\
\text { concentration } \\
\text { database }\end{array}$ & $\begin{array}{c}\text { Dietary intake of MelQx (adjusted } \\
\text { odds ratio (aOR) 1.88, } 95 \% \mathrm{Cl} 1.45- \\
2.43 \text { ), DiMelQx (aOR } 1.7395 \% \\
\mathrm{Cl} 1.34-2.23 \text { ), and meat-derived } \\
\text { mutagenic activity (aOR } 1.8495 \% \\
\mathrm{Cl} 1.42-2.39 \text { ) showed statistically } \\
\text { significant associations with risk of } \\
\text { colon cancer }\end{array}$ & $\begin{array}{l}\text { Results supports that HCAs } \\
\text { and PAHs derived from red } \\
\text { meat, but not white meat, } \\
\text { are a potential environmental } \\
\text { pathway of colon cancer } \\
\text { carcinogenesis }\end{array}$ \\
\hline
\end{tabular}

\begin{tabular}{|c|c|c|c|c|}
\hline $\begin{array}{l}\text { Ollberding et al. } \\
\qquad[14] \\
\text { Meat consumption, } \\
\text { HCAs, and CRC }\end{array}$ & $\begin{array}{l}\text { Prospective cohort study } \\
\text { conducted within the } \\
\text { Multiethnic Cohort Study; } \\
165,717 \text { participants-greater } \\
\text { consumption of total, red, or } \\
\text { processed meat associated with } \\
\text { CRC risk and } 131,763 \text { participants } \\
\text { who completed a follow-up } \\
\text { questionnaire that included a } \\
\text { meat-cooking module; } 3,404 \text { and } \\
1,757 \text { CRC cases }\end{array}$ & $\begin{array}{l}\text { Detailed quantitative } \\
\text { FFQ that obtained } \\
\text { the frequency and } \\
\text { quantity of food items } \\
\text { consumed during the } \\
\text { preceding year }\end{array}$ & $\begin{array}{l}\text { No association with CRC risk } \\
\text { detected for density-adjusted total } \\
\text { meat or processed meat intake or } \\
\text { for total or specific HCA intake (RR } \\
0.90,95 \% \mathrm{Cl} 0.76-1.05 \text { ) comparing } \\
\text { quintiles of dietary exposure or } \\
\text { using continuous variables }\end{array}$ & $\begin{array}{c}\text { Results do no support a role } \\
\text { for meat or HCAs from meat } \\
\text { in etiology of CRC; cannot rule } \\
\text { out modest effect }\end{array}$ \\
\hline $\begin{array}{l}\text { Parr et al. [15] } \\
\text { Meat intake, } \\
\text { cooking methods, } \\
\text { and CRC }\end{array}$ & $\begin{array}{l}\text { Prospective cohort study; } \\
\text { population-based Norwegian } \\
\text { Women and Cancer cohort; } \\
84,538 \text { women; } 459 \text { colon and } \\
215 \text { rectal cancer cases with } \\
\text { follow-up }\end{array}$ & $\begin{array}{l}\text { FFQ that covered } \\
\text { habitual, but not } \\
\text { total diet, during the } \\
\text { previous year }\end{array}$ & $\begin{array}{l}\text { The findings of the study do not } \\
\text { support an association between } \\
\text { the risk of CRC and intake of red } \\
\text { meat or cooking methods (HR } \\
0.70,95 \% \mathrm{Cl} 0.33-1.48 \text { ) }\end{array}$ & $\begin{array}{l}\text { Did not support an association } \\
\text { between CRC risk and intake } \\
\text { of red meat or meat cooking } \\
\text { methods, but a high processed } \\
\text { meat intake was associated } \\
\text { with increased risk of proximal } \\
\text { colon, distal and rectal cancer }\end{array}$ \\
\hline $\begin{array}{l}\text { Tabatabaei et al. } \\
\qquad 16] \\
\text { Meat consumption, } \\
\text { cooking practices, } \\
\text { and CRC }\end{array}$ & $\begin{array}{c}\text { Case-control study in the Western } \\
\text { Australian Bowel Health Study; } \\
567 \text { incident CRC cases and } 713 \\
\text { controls }\end{array}$ & $\begin{array}{l}\text { Questionnaires on } \\
\text { lifestyle and meat } \\
\text { consumption }\end{array}$ & $\begin{array}{c}\text { Amount of red baked meat } \\
\text { consumed statistically significant } \\
\text { inverse trend of association with } \\
\text { CRC (OR } 0.73,95 \% \mathrm{Cl} 0.53-1.01 \text { ). } \\
\text { No other statistically significant or } \\
\text { meaningful associations with any } \\
\text { of the types of meat cooked by } \\
\text { any method and CRC risk }\end{array}$ & $\begin{array}{c}\text { Data does not support } \\
\text { the hypothesis that meat } \\
\text { consumption is a risk factor } \\
\text { for CRC }\end{array}$ \\
\hline
\end{tabular}

meat and HCAs had a modest effect on the development of CRC due to residual confounding (e.g., differences in the approaches used to classify and define red and processed meat, variable recipes, etc.) [14]. Parr et al. [15] examined associations of meat intake with incident cancer of the proximal colon, distal colon, and rectum in the population-based Norwegian Women and Cancer cohort. Cooking methods of meat were also examined in a subsample of the cohort. The findings of the study do not support an association between CRC and intake of red meat or cooking methods (HR 0.70, 95\% Cl 0.33-1.48) [15]. Tabatabaei et al. [16] conducted a population-based case-control study in the Western Australian Bowel Health Study that investigated the association between meat consumption, cooking practices, and $\mathrm{CRC}$ risk. The findings from the study do not support the hypothesis that meat intake is a risk factor for CRC (OR 0.73, 95\% Cl 0.53-1.01) [16].

\section{Nitrates/Nitrites and processed meat}

Processed meats are preserved with nitrite, which can react with degradation products of amino acids to form $\mathrm{N}$-nitroso 
Table 3 Association between nitrates/nitrites found in processed meat and CRC.

\begin{tabular}{|c|c|c|c|c|}
\hline Author/Topic & $\begin{array}{l}\text { Study Design/ } \\
\text { Population }\end{array}$ & $\begin{array}{c}\text { Dietary Assessment } \\
\text { Method }\end{array}$ & Results & Major Findings/Conclusions \\
\hline $\begin{array}{l}\text { Miller et al. [12] } \\
\text { Meat-related } \\
\text { compounds and CRC }\end{array}$ & $\begin{array}{c}\text { Case-control study; } 989 \\
\text { cases } / 1,033 \text { healthy } \\
\text { controls }\end{array}$ & $\begin{array}{c}\text { FFQ w/a meat-specific } \\
\text { module }\end{array}$ & $\begin{array}{l}\text { Significant positive association for } \\
\text { nitrites/nitrates and proximal colon } \\
\text { cancer (OR 1.57, 95\% Cl 1.06-2.59) }\end{array}$ & $\begin{array}{c}\text { HCAs, PAHs, nitrites, and } \\
\text { nitrates may be involved in CRC } \\
\text { etiology }\end{array}$ \\
\hline $\begin{array}{l}\text { Parr et al. [15] } \\
\text { Meat intake, cooking } \\
\text { methods, and CRC }\end{array}$ & $\begin{array}{l}\text { Prospective cohort } \\
\text { study; population- } \\
\text { based Norwegian } \\
\text { Women and Cancer } \\
\text { cohort; } 84,538 \text { women } \\
459 \text { colon and } 215 \\
\text { rectal cancer cases } \\
\text { with follow-up }\end{array}$ & $\begin{array}{l}\text { FFQ that covered } \\
\text { habitual, but not } \\
\text { total diet, during the } \\
\text { previous year }\end{array}$ & $\begin{array}{l}\text { Processed meat intake } \geq 60 \text { vs. }<15 \mathrm{~g} / \\
\text { day was associated with significantly } \\
\text { increased cancer risk in all subsites. }\end{array}$ & $\begin{array}{l}\text { Did not support an association } \\
\text { between CRC risk and intake } \\
\text { of red meat or meat cooking } \\
\text { methods, but a high processed } \\
\text { meat intake was associated with } \\
\text { increased risk of proximal colon, } \\
\text { distal and rectal cancer }\end{array}$ \\
\hline $\begin{array}{l}\text { Dellavalle et al. [17] } \\
\text { Dietary nitrate and } \\
\text { nitrite intake and CRC } \\
\text { risk }\end{array}$ & $\begin{array}{l}\text { Prospective cohort } \\
\text { study; cohort from the } \\
\text { Shanghai Women's } \\
\text { Health Study of } 73,118 \\
\text { women age } 40-70 ; 619 \\
\text { CRC cases }\end{array}$ & 77-item FFQ & $\begin{array}{l}\text { Nitrate intake was not associated with } \\
\text { CRC risk (HR } 1.0895 \% \mathrm{Cl} 0.73-1.59 \text { ). } \\
\text { Those with vitamin C intake below } \\
\text { the median ( } 83.9 \mathrm{mg} / \text { day) and as a } \\
\text { result had higher potential exposure } \\
\text { to NOCs, CRC risk increased with } \\
\text { increasing quintiles of nitrate intake } \\
\text { (highest vs. lowest quintile HR } 2.45 \\
95 \% \mathrm{Cl} 1.15-5.18 \text { ) }\end{array}$ & $\begin{array}{l}\text { An association between } \\
\text { dietary nitrate and nitrate } \\
\text { was not observed; however, } \\
\text { findings suggest that a high } \\
\text { intake of nitrate among } \\
\text { subgroups expected to have } \\
\text { high endogenous N-nitroso } \\
\text { compouns (NOC) exposure } \\
\text { (those with low vitamin C } \\
\text { intake) are associated with } \\
\text { increased CRC risk }\end{array}$ \\
\hline $\begin{array}{l}\text { Hu et al. [18] } \\
\text { Salt, processed meat, } \\
\text { and cancer }\end{array}$ & $\begin{array}{c}\text { Case-control study, } \\
19,732 \text { cases }\end{array}$ & 69-item FFQ & $\begin{array}{l}\text { Significant results were found for } \\
\text { processed meat and risk of CRC (OR } \\
1.5,95 \% \mathrm{Cl} 1.2-1.8 \text { ) }\end{array}$ & $\begin{array}{l}\text { Findings add to the evidence } \\
\text { that high consumption of salt } \\
\text { and processed meat may play } \\
\text { a role in the etiology of several } \\
\text { cancers-stomach, pancreas, } \\
\text { lung, prostate, testis, kidney, } \\
\text { and bladder }\end{array}$ \\
\hline $\begin{array}{l}\text { De Stefani et al. [19] } \\
\text { Processed meat and } \\
\text { cancer }\end{array}$ & $\begin{array}{l}\text { Case-control study } \\
\text { in Uruguay; } 6,060 \\
\text { participants }(3,528 \\
\text { cases and 2,532 } \\
\text { controls) }\end{array}$ & 64-item FFQ & $\begin{array}{c}\text { Positive association between } \\
\text { processed meat and CRC (OR 2.39, 95\% } \\
\qquad \mathrm{Cl} 1.76-3.24)\end{array}$ & $\begin{array}{l}\text { Processed meat intake could } \\
\text { be a powerful multiorgan } \\
\text { carcinogen affecting CRC and } \\
\text { also the stomach, esophagus, } \\
\text { and lungs }\end{array}$ \\
\hline
\end{tabular}

compounds (NOCs), such as nitrosamines or nitrosamides. These compounds can form during the process of meat curing or within the body from dietary consumption of nitrate/nitrite. Several NOCs are known carcinogens in humans [1]. Based on the convincing evidence of the carcinogenic effect of these compounds, it is recommended to avoid processed meat.

Two prospective cohort and three case-control studies support the association between processed meat and CRC risk. Parr et al. [15] found that processed meat intake $\geq 60$ g versus $<15$ g per day was associated with a significantly high risk of CRC (HR 1.69, $95 \% \mathrm{Cl} 1.05-2.72$ ). Another prospective cohort study found no association between nitrate intake and CRC risk (HR 1.08, 95\% $\mathrm{Cl}$ 0.73-1.59); however, since vitamin $\mathrm{C}$ may inhibit the reactions that form NOCs, the study did find that in women with a vitamin $\mathrm{C}$ intake below the median ( $83.9 \mathrm{mg} /$ day) leading to a potential increase in exposure to NOCs, a greater intake of nitrates was associated with a greater risk of CRC between the highest and lowest quintiles (HR 2.45, 95\% Cl 1.15-5.18) [16,17]. Miller et al. [12] found a significant positive association for nitrites/nitrates and proximal colon cancer (OR 1.57, 95\% Cl 1.06-2.59). A casecontrol study by Hu et al. [18] assessed the association between the risk of various cancers and added table salt and processed meat. Significant results were found for processed meat and increased risk of CRC (OR 1.5, 95\% Cl 1.2-1.8), indicating that high consumption of salt and processed meat may play a role in several cancer etiologies [18]. A study by De Stefani et al. [19] assessed CRC risk and processed meat consumption using a multisite case-control design in 6,060 participants in Uruguay. A positive association was found for CRC with high consumption of processed meat (OR 2.39, 95\% Cl 1.76-3.24) [19].

\section{Heme iron in meat}

Iron is a potentially toxic, tightly regulated mineral that plays a central role in oxidative metabolism and is a component of several enzymes. A catalytic reaction of free iron can generate free radicals that may lead to oxidative damage of DNA, protein, and membrane lipids of cells; therefore, the body strictly regulates iron transport and metabolism to reduce the likelihood of oxidative damage [20]. Heme iron is found in foods of animal origin, while non-heme iron is found in plant foods. High intakes of red meat may result in more heme iron absorption leading to greater oxidative stress and increasing the potential for DNA damage [1]. In addition, dietary heme can induce colonic cytotoxicity and hyperproliferaion leading to inflammation [21]. 
Table 4 Association between heme iron in meat and CRC.

\begin{tabular}{|c|c|c|c|c|}
\hline Citation/Topic & Study Design/Population & $\begin{array}{l}\text { Dietary Assessment } \\
\text { Method }\end{array}$ & Results & Major Findings/Conclusions \\
\hline $\begin{array}{l}\text { Kato et al. [22] } \\
\text { Dietary iron, smoking, } \\
\text { and intestinal bacteria } \\
\text { and CRC }\end{array}$ & $\begin{array}{l}\text { Case-control study with } \\
1205 \text { cases and } 1547 \\
\text { controls between the ages } \\
\text { of } 45 \text { and } 80\end{array}$ & $\begin{array}{l}\text { Phone interview with } \\
\text { structured questionnaires } \\
\text { regarding usual diet }\end{array}$ & $\begin{array}{c}\text { CRC was increased by heme iron } \\
\text { intake (OR } 1.47,95 \% \mathrm{Cl} 1.14- \\
1.89)\end{array}$ & $\begin{array}{l}\text { Heme iron from meat may } \\
\text { increase the risk of CRC }\end{array}$ \\
\hline $\begin{array}{l}\text { Gilseng et al. [23] } \\
\text { Dietary heme iron and } \\
\text { CRC risk }\end{array}$ & $\begin{array}{l}\text { Prospective cohort study } \\
\text { from the Netherlands } \\
\text { Cohort Study; } 4026 \\
\text { subcohort members, } 435 \\
\text { colon and } 140 \text { rectal cancer } \\
\text { patients }\end{array}$ & $\begin{array}{c}\text { 150-item semiquantitative } \\
\text { FFQ }\end{array}$ & $\begin{array}{l}\text { Heme iron associated with } \\
\text { increased risk of CRC harboring } \\
\text { activating gene mutations in } \\
\text { KRAS (Kirsten ras) (HR } 1.7195 \% \\
\text { CI 1.15-2.57) and CRC without } \\
\text { truncating mutations in APC } \\
\text { (adenomatous polyposis coli) } \\
\text { (HR } 1.7995 \% \mathrm{Cl} 1.23-2.60 \text { ) }\end{array}$ & $\begin{array}{l}\text { Positive association found } \\
\text { between dietary heme } \\
\text { iron and CRC risk, with the } \\
\text { suggestion of alkylating } \\
\text { rather than oxidative DNA- } \\
\text { damaging mechanisms are } \\
\text { involved in carcinogenesis } \\
\text { of CRC }\end{array}$ \\
\hline $\begin{array}{c}\text { Hara et al. [24] } \\
\text { Zinc, heme iron, and CRC }\end{array}$ & $\begin{array}{l}\text { Prospective cohort study } \\
\text { in Japan; } 39,721 \text { men and } \\
45,376 \text { women age } 45-74\end{array}$ & 138-item FFQ & $\begin{array}{c}\text { No association was found linking } \\
\text { zinc and heme iron intake with } \\
\text { CRC in either Japanese men } \\
\text { (HR } 1.06,95 \% \mathrm{Cl} 0.79-1.42 \text { ) or } \\
\text { women (HR 0.88, } 95 \% \mathrm{Cl} 0.61 \text { - } \\
1.29 \text { ) }\end{array}$ & $\begin{array}{l}\text { Results in a Japanese } \\
\text { population with lower } \\
\text { intakes and different major } \\
\text { food sources of zinc and } \\
\text { heme iron in comparison to } \\
\text { the Western diet suggest } \\
\text { zinc and heme iron intake } \\
\text { not associated with CRC }\end{array}$ \\
\hline $\begin{array}{l}\text { Zhang et al. [25] } \\
\text { Zinc, heme iron, and CRC }\end{array}$ & $\begin{array}{l}\text { Prospective cohort study in } \\
\text { Nurses' Health Study and } \\
\text { Health Professionals Follow- } \\
\text { up Study; } 2,114 \text { incident CRC } \\
\text { cases }\end{array}$ & FFQ & $\begin{array}{l}\text { Total iron intake, intake of } \\
\text { dietary iron, and supplement } \\
\text { uses did not have a significant } \\
\text { association with CRC (RR 1.10, } \\
\quad 95 \% \mathrm{Cl} 0.93-1.30 \text { ) }\end{array}$ & $\begin{array}{l}\text { Does not support strong } \\
\text { roles of zinc and heme iron } \\
\text { intake in CRC risk }\end{array}$ \\
\hline $\begin{array}{c}\text { Dietary and } \\
\text { supplemental iron and } \\
\text { CRC }\end{array}$ & $\begin{array}{l}\text { Case-control study in } \\
\text { Pennsylvania; } 1005 \text { incident } \\
\text { cases and } 1062 \text { controls }\end{array}$ & $\begin{array}{l}\text { Modified FFQ that included } \\
\text { supplement use and a } \\
\text { meat-specific module }\end{array}$ & $\begin{array}{c}\text { No significant associations } \\
\text { between heme iron or total iron } \\
\text { intake and } \mathrm{CRC} \text { incidence (OR } \\
0.70,95 \% \mathrm{Cl} 0.44-1.11 \text { ) } \\
\text { Supplemental iron intake of } \\
\text { more than } 18 \mathrm{mg} / \text { day versus } \\
\text { non was positively associated } \\
\text { with CRC incidence (OR } 2.31 \text {, } \\
95 \% \mathrm{Cl} 1.48-3.59)\end{array}$ & $\begin{array}{l}\text { Consumption of more than } \\
18 \mathrm{mg} / \text { day of supplemental } \\
\text { iron may increase risk for } \\
\text { CRC, but heme or total iron } \\
\text { was not found to have an } \\
\text { association with CRC }\end{array}$ \\
\hline
\end{tabular}

Table 4 summarizes five studies conducted after the SER that explore the association of iron with CRC risk. Two studies supported the association, while three of the studies concluded that the evidence is insufficient to confirm the association. Kato et al. [22] conducted a population-based case-control study investigating the associations of dietary iron, smoking, and intestinal bacteria with the risk of CRC. Results showed that CRC was increased by heme iron intake (OR 1.47, 95\% Cl 1.14-1.89) [22]. The study discussed the importance of heme iron derived from animal meat rather than total iron intake as a risk for CRC. In a 2013 prospective cohort study, researchers found a significant association between CRC risk and heme iron intake activating gene mutations in $\mathrm{KRAS}^{3}$ (a step that may lead to cancer development) (HR 1.71, 95\% Cl 1.15-2.57) and risk of CRC without truncating mutations in $\mathrm{APC}^{4}$ (adenomatous polyposis coli) (HR 1.79, 95\%

${ }^{3}$ KRAS: Also referred to as GTPase KRas and V-Ki-ras2 Kirsten rat sarcoma viral oncogene homolog. This is a protein encoded by the KRAS gene in humans. A mutation may lead to the development of many cancers.

${ }^{4} \mathrm{APC}$ : Adenomatous polyposis coli, also known as deleted in polyposis 2.5 (DP2.5). This is a protein encoded by the APC gene in humans. Colorectal cancer may result due to a mutation of this gene
Cl 1.23-2.60) [23]. Results indicate that an alkylating mechanism may underlie the positive association between dietary heme and CRC risk, versus a DNA-damaging mechanism [23].

Two prospective cohort studies found no association of heme iron intake and CRC risk. A large population-based prospective study examined the association between intake of zinc and heme iron and risk of CRC in a general Japanese population [24]. No association was found linking zinc and heme iron intake with CRC in either Japanese men (HR 1.06, 95\% Cl 0.79-1.42) or women (HR 0.88, 95\% Cl 0.61-1.29) [24]. Another study examined zinc and heme iron intake and CRC risk using data from the Nurses' Health Study and Health Professionals Follow-Up Study, which included 2114 incident CRC cases [25]. Results showed total iron intake, intake of dietary iron, and supplement use did not have a significant association with CRC (RR 1.10, 95\% Cl 0.93-1.30); suggesting that heme iron intake does not have a strong role in CRC risk [25]. Finally, Ashmore et al. [26] investigated 1,005 incident cases and 1,062 controls to examine the association of dietary and supplemental iron intake with CRC. No significant association was found for heme iron or total iron intake and 
incidence of CRC (OR 0.70, 95\% Cl 0.44-1.11) [26]. Intake of supplemental iron of more than $18 \mathrm{mg} /$ day versus $0 \mathrm{mg} /$ day had a positive association with incidence of CRC (OR 2.31, 95\% $\mathrm{Cl} 1.48-3.59)$, suggesting that consumption of $>18 \mathrm{mg} /$ day of supplemental iron may increase CRC risk, although these data do not support the association of total or heme iron intake with risk of CRC [26].

\section{Discussion}

This paper summarized new study findings regarding the proposed relationships between red and processed meat consumption and CRC that have been published since the 2011 CUP Report. This topic is particularly relevant given the consumption of red and processed meat in the US and the incidence of CRC. Overall, findings of the updated literature continue to support the WCRF/ AICR guidelines and the importance of limiting the consumption of red meat to 18 ounces per week and to minimize processed meat consumption altogether for the prevention of CRC. A doseresponse relationship between red and processed meat and CRC lends further credence to these findings reported $[27,28]$, with additional support highlighting the proposed underlying mechanistic roles of HCAs/PAHs, NOCs, and heme iron. To date, the exact role of these compounds in CRC development remains elusive, yet they are clearly important in this diet-disease relationship and warrant further investigation [29].

While the data linking meat and CRC is relatively strong, some inconsistencies are evident between studies and may be attributed to the inherent difficulties of dietary assessment. In the studies reviewed, each employed either a food frequency questionnaire (FFQ) or another form of self-administered questionnaire to collect dietary assessment data (e.g., food record, food diaries). FFQs are a valid and reliable method to measure dietary intake and to assess its relationship with outcomes. They are advantageous and applied widely because they are representative of usual intake, can be used in very large studies, rank participants according to intake for analysis, and provide a cost-effective way to collect critical dietary data [30]. Despite these advantages, FFQs are prone to error due to recall bias and the subjective nature of the assessment tool [30]. Recall bias is an inherent limitation, as FFQs rely on the participants' memory over a specified period of time, typically several months to a year. Some degree of measurement error can be attributed to the subjective nature of these tools, since people have the tendency to underreport what they have eaten, especially when it requires recording. In addition, participants may inaccurately account what they have eaten in the past with response distortion of what they consider healthy versus unhealthy [31]. Because FFQs depict usual intake they are considered less accurate when assessing absolute intake of a specific food group or nutrient, such as meat consumption in these studies. Further, several studies used different FFQs or other comparable dietary assessment questionnaires. While most appropriate for the population under study, these methodological differences pose limitations for the direct comparison of responses and outcomes assessment across studies. All of these previous investigation utilized statistical methods to control for potential confounders, including age, sex, smoking, alcohol intake, body weight, BMI, and family history; however, residual confounding may still bias or impede our abilities to depict more precise diet-disease relationships due to the natural variations in dietary intake not detected by these dietary assessment methodologies. Finally, FFQs and other self-administered dietary assessment methods do not take into consideration several influencing factors, such as cooking methods or temperature, which are now recognized as important considerations in CRC development [32].

While the negative associations between red and processed meat consumption and CRC continue to build, a broad body of evidence supports that plant-based dietary patterns, fruit and vegetable consumption, and specific plant constituents may reduce the overall risk of cancer, as well as cancer recurrence. Several studies have identified dietary patterns to investigate the association of the total diet on CRC risk. While the study designs, methods, participant populations, and derived dietary patterns differ, the three reviews [33-35], three case-control [3637], and two prospective cohort studies [38-40] all concluded that meat-based diets are associated with an increased risk of CRC and that plant-based diets, rich in fruit, vegetables, and low in red and processed meat, may reduce CRC risk. These findings are consistent with Tantamango-Bartley et al. [41] who found that vegetarian versus non-vegetarian dietary patterns were associated with significantly reduced cancer incidence (HR 0.92, 95\% Cl 0.85-0.99). This study also reported that vegan dietary practices were even more protective for overall cancer incidence (HR 0.66, 95\% Cl 0.47-0.92) [41]. Lanou and Svenson [42] conducted an analysis of recent reports on cancer risk in vegetarians and found that the direct and indirect evidence supported that vegetarian diets are useful in reducing cancer risk. Findings from a systematic review and meta-analysis exploring cancer incidence in vegetarians supported that vegetarians have significantly lower overall cancer incidence than non-vegetarians (RR 0.82, 95\% Cl 0.67-0.97) [43]. Although there is a cause and effect relationship between red and/or processed meat consumption and CRC, strong evidence exists to support a plantbased diet approach for overall cancer prevention.

In support of the WCRF/AICR recommendations, many professional organizations also promote a plant-based diet and limiting red and processed meat consumption for the general prevention of cancer, not specifically CRC. The Academy of Nutrition and Dietetics (AND) position paper on vegetarian diets reports that appropriately planned vegetarian diets are nutritionally adequate and are associated with a lower body mass index and a reduced incidence of cancer overall [44]. The American Cancer Society (ACS) supports that the most important ways to reduce cancer risk include maintenance of a healthy weight, regular physical activity, and consuming a mostly plant-based diet limiting saturated fat [45]. The ASC guidelines specifically recommend limiting red and processed meat, while consuming at least two and a half cups of fruit and vegetables each day [45]. The World Health Organization (WHO) also states that dietary habits including diets high in fruits and vegetables may have a protective effect against a multitude of cancers, 
while consuming excess red and processed meat may have an association with increased CRC risk $[46,47]$. Although there are several different recommendations by these authoritative groups, it is clear that dietary patterns (e.g., plant based) and dietary intake (e.g., limited meat consumption) are the cornerstone of cancer prevention.

\section{Conclusions}

With high cancer incidence rates and mounting evidence regarding the role of diet in cancer prevention, dietary intervention in now more than ever crucial to help reduce the number of new cancer cases each year. The 2011 CUP Report supports the AICR guidelines that recommend limiting red and processed meat and consuming a plant-based diet for primary cancer prevention. Evidence since the report continues to reaffirm the relationship between red and processed meat and $\mathrm{CRC}$ risk. The proposed mechanisms underlying the association include HCAs/PAHs, N-nitroso compounds, and heme iron; however, these relationships are far from definitive. All of these compounds are implicated in the carcinogenesis process and the strongest association to date is found for CRC. A plant-based diet not only minimizes compounds hypothesized to increase cancer risk, but emphasizes high intakes of fruits and vegetables to increase to increase the consumption of protective compounds found in plant-based foods. Based on the continually emerging evidence, the ideal recommendation for cancer prevention involves making healthy lifestyle choices. Included in this recommendation is maintaining a healthy weight, engaging in regular physical activity and consuming a diet that emphasizes plant sources, reduced consumption of red and processed meat, and increasing plant-based whole foods. 


\section{References}

1 World Cancer Research Fund/American Institute for Cancer Research (2007) Food, Nutrition, Physical Activity, and the Prevention of Cancer: a Global Perspective. Washington DC: AICR.

2 http://www.cancer.gov/about-cancer/causes-prevention/risk/ obesity/obesity-fact-sheet

3 American Cancer Society (2015) Cancer Facts \& Figures 2015. Atlanta: American Cancer Society.

4 World Cancer Research Fund/American Institute for Cancer Research (2011) Continuous Update Project Report. Food, Nutrition, Physical Activity, and the Prevention of Colorectal Cancer.

5 Ferrucci LM, Sinha R, Huang WY, Berndt SI, Katki HA, et al. (2012) Meat consumption and the risk of incident distal colon and rectal adenoma. Br J Cancer 106: 608-616.

6 Takachi R, Tsubono Y, Baba K, Inoue M, Sasazuki S, et al. (2011) Red meat intake may increase the risk of colon cancer in Japanese, a population with relatively low red meat consumption. Asia Pac J Clin Nutr 20: 603-612.

7 Bernstein AM, Song M, Zhang X, Pan A, Wang M, et al. (2015) Processed and unprocessed red meat and risk of colorectal cancer: analysis by tumor location and modification by time. PLoS One 10 : e0135959.

8 Aune D, De Stefani E, Ronco A, Boffetta P, Deneo-Pellegrini $H$, et al. (2009) Meat consumption and cancer risk: A case-control study in Uruguay. Asian Pac J Cancer Prev 10: 429-436.

9 De Stefani E, Ronco AL, Boffetta P, Deneo-Pellegrini H, Correa P, et al. (2012) Nutrient-derived dietary patterns and risk of colorectal cancer: a factor analysis in Uruguay. Asian Pac J Cancer Prev 13: 231-235.

10 Spencer EA, Key TJ, Appleby PN, Dahm CC, Keogh RH, et al. (2010) Meat, poultry and fish and risk of colorectal cancer: pooled analysis of data from the UK dietary cohort consortium. Cancer Causes Control 21: 1417-1425.

11 Rohrmann S, Hermann, Linseisen J (2009) Heterocyclic aromatic amine intake increases colorectal adenoma risk: findings from a prospective European cohort study. Am J Clin Nutr 89: 1418-1424.

12 Miller PE, Lazarus P, Lesko SM, Cross AJ, Sinha R, et al. (2013) Meatrelated compounds and colorectal cancer risk by anatomical subsite. Nutr Cancer 65: 202-226.

13 Helmus DS, Thompson CL, Zelenskiy S, Tucker TC, Li L (2013) Red meat-derived heterocyclic amines increases risk of colorectal cancer: a population-based case-control study. Nutr Cancer 65: 1141-1150.

14 Ollberding NJ, Wilkens LR, Henderson BE, Kolonel LN, Marchand L (2012) Meat consumption, heterocyclic amines and colorectal cancer risk: the Multiethnic Cohort Study. Int J Cancer 131: E1125-E1133.

15 Parr CL, Hjartaker A, Lund E, Veirerod MB (2013) Meat intake, cooking methods and risk of proximal colon, distal colon and rectal cancer: the Norwegian Women and Cancer (NOWAC) cohort study. Int J Cancer 133: 1153-1163.

16 Tabatabaei SM, Fritschi L, Knuiman MW, Boyle T, lacopetta BJ, et al. (2011) Meat consumption and cooking practices and the risk of colorectal cancer. Eur J Clin Nutr 65: 668-675.

17 DellaValle CT, Xiao Q, Yang G, Shu XO, Aschebrook-Kilfoy B, et al. (2014) Dietary nitrate and nitrite intake and risk of colorectal cancer in the Shanghai Health Study. Int J Cancer 134: 2917-2926.
18 Hu J, La Vecchia C, Morrison H, Negri E, Mery L, et al. (2011) Salt, processed meat and the risk of cancer. Eur J Cancer Prev 20: 132-139.

19 De Stefani E, Boffetta P, Ronco AL, Deneo-Pellegrini H, Correa P, et al. (2012) Processed meat consumption and risk of cancer: a multisite case-control study in Uruguay. Br J Cancer 107: 1584-1588.

20 Udupi S, Ghugre P, Cokhale C (2012) Iron, oxidative stress, and health. Oxidative Stress - Molecular Mechanisms and Biological Effects. Lushchak V InTech pp: 73-108.

21 Sesink ALA, Termont DSML, Kleibeuker JH, Van der Meer R (1999) Red meat and colon cancer: the cytotoxic and hyperproliferative effects of dietary heme. Cancer Research 59: 5704-5709.

22 Kato I, Boleij A, Kortman GA, Roelofs R, Djuirc Z, et al. (2013) Partial associations of dietary iron, smoking and intestinal bacteria with colorectal cancer risk. Nutr Cancer 65: 169-177.

23 Gilseng AM, Fransen F, de Kok TM, Goldbohm AR, Schouten LJ, et al. (2013) Dietary heme iron and the risk of colorectal cancer with specific mutations in KRAS and APC. Carcinogenesis 34: 2757-2766.

24 Hara A, Sasazuki S, Inoue M, Iwasaki M, Shimazu T, et al. (2012) Zinc and heme iron intakes and risk of colorectal cancer: a populationbased prospective cohort study in Japan. Am J Clin Nutr 96: 864-873.

25 Zhang X, Giovannucci EL, Smith-Warner SA, Wu K, Fuchs CS, et al. (2011) A prospective study of intakes of zinc and heme iron and colorectal cancer risk in men and women. Cancer Causes Control 22: 1627-1637.

26 Ashmore JH, Lesko SM, Miller PE, Cross AJ, Muscat JE, et al. (2013) Association of dietary and supplemental iron and colorectal cancer in a population-based study. Eur J Cancer Prev 22: 506-511.

27 Smolinska K, Paluszkiewicz P (2010) Risk of colorectal cancer in relation to frequency and total amount of red meat consumption. Systematic review and meta-analysis. Arch Med Sci 6: 605-610.

28 Chan DSM, Lau R, Aune D, Vieira R, Greenwood D, et al. (2011) Red and processed meat and colorectal cancer incidence: meta-analysis of prospective studies. PLoS One 6: e20456.

29 Cross AJ, Ferrucci LM, Risch A, Graubard BI, Ward MH, et al. (2010) A large prospective study of meat consumption and colorectal cancer risk: an investigation of potential mechanisms underlying this association. Cancer Res 70: 2406-2414.

30 Hu FB, Rimm E, Smith-Warner SA, Feskanich D, Stampfer MJ, et al. (1999) Reproducibility and validity of dietary patterns assessed with a food-frequency questionnaire. Am J Clin Nutr 69: 243-249.

31 Bedard D, Shatenstein B, Nadon S (2004) Underreporting of energy intake from a self-administered food-frequency questionnaire completed by adults in Montreal. Public Health Nutr 7: 675-681.

32 Zheng W, Lee SA (2009) Well-done meat intake, heterocyclic amine exposure, and cancer risk. Nutr Cancer 61: 437-446.

33 Miller PE, Lesko SM, Muscat JE, Lazarus P, Hartman TJ (2010) Dietary patterns and colorectal adenoma and cancer risk: a review of the epidemiological evidence. Nutr Cancer 62: 413-424.

34 Randi G, Edefonti V, Ferraroni M, La Vecchia C, Decarli A (2010) Dietary patterns and the risk of colorectal cancer and adenomas. Nutr Rev 68: 389-408.

35 Fung TT, Brown LS (2013) Dietary patterns and the risk of colorectal cancer. Curr Nutr Rep 2: 48-55.

36 Chen Z, Wang PP, Woodrow J, Zhu Y, Roebothan B, et al. (2015) Dietary patterns and colorectal cancer: results from a Canadian population-based study. Nutr J 14. 
37 Satia JA, Tseng M, Galanko JA, Martin C, Sandler RS (2009) Dietary patterns and colon cancer risk in Whites and African Americans in the North Carolina Colon Cancer Study. Nutr Cancer 61: 179-93.

38 Safari A, Shariff ZM, Kandiah M, Rashidkhani B, Fereidooni F (2013) Dietary patterns and risk of colorectal cancer in Tehran Provicne: a case-control study. BMC Public Health 13.

39 Zhu Y, Wu H, Wang PP, Savas S, Woodrow J, et al. (2013) Dietary patterns and colorectal cancer recurrence and survival: a cohort study. BMJ Open 3.

40 Orlich MJ, Singh PN, Sabate J, Fan J, Sveen L, et al. (2015) Vegetarian dietary patterns and the risk of colorectal cancers. JAMA Intern Med 175: 767-776.

41 Tantamango-Bartley Y, Jaceldo-Siegl K, Fran J, Fraser G (2013) Vegetarian diets and the incidence of cancer in a low-risk population. Cancer Epidemiol Biomarkers Prev 22: 286-294.
42 Lanou AJ, Svenson B (2010) Reduced cancer risk in vegetarians: an analysis of recent reports. Cancer Manag Res 3: 1-8.

43 Huang T, Yang B, Zheng J, Li G, Wahlqvist ML, et al. (2012) Cardiovascular disease mortality and cancer incidence in vegetarians: a metaanalysis and systematic review. Ann Nutr Metab 60: 233-240.

44 Craig WJ, Mangels, AR, American Dietetic Association (2009) Position of the American Dietetic Association: vegetarian diets. J Am Diet Assoc 109: 1266-1282.

45 Kushi LH, Doyle C, McCullough M, Rock CL, Demark-Wahnefried W, et al. (2012) American Cancer Society Guidelines on nutrition and physical activity for cancer prevention: reducing the risk of cancer with healthy food choices and physical activity. CA Cancer J Clin 62: 30-67.

46 http://www.who.int/elena/titles/fruit_vegetables_ncds/en/

47 http://www.who.int/features/qa/cancer-red-meat/en/ 